\title{
Effect of interest rate on economic performance: evidence from Islamic and non-Islamic economies
}

\author{
Saba Mushtaq ${ }^{*}$ (D) and Danish Ahmed Siddiqui
}

\author{
* Correspondence: \\ sabamushtaq238@gmail.com \\ Karachi University Business School, \\ University of Karachi, Karachi, \\ Pakistan
}

\begin{abstract}
Background: Saving and investment are two of the most important tools for economic growth. The interest rate has always been considered an important determinant of saving and investment. However, according to Islamic teachings, riba or earning interest on saving or investment is forbidden, and thus, many Muslims try to avoid earning income from the interest rate. Therefore, the aim of this study is to assess the effects of this religious guideline on the financial decisions of an Islamic country's population and its impact on saving and investment.
\end{abstract}

Methods: We applied the random effect and system generalized method of moments (GMM) model separately to data of 17 non-Islamic and 17 Islamic countries from 2005 to 2013.

Results: The results suggest that people in Islamic countries are not concerned about the interest rate on saving, but in non-Islamic countries, the interest rate, per capita income, and inflation have significant positive impacts, and national expenditure has a significant negative impact on saving. However, in Islamic countries, remittances received and national expenditure have negative significant impacts, and per capita income has a positive significant impact on saving. In the case of investment, interest rate and inflation show a negative effect on investment while trade affects investment positively in both Islamic and non-Islamic countries. Furthermore, domestic credit provided by banks has a negative significant effect on investment in non-Islamic countries, while in Islamic countries, remittances show a positive significant impact on investment.

Conclusions: The governments and policy makers of Islamic countries should not imitate the economic policies of non-Islamic countries because religious factors play an important role in the interest rate-saving relationship. Instead, they should increase per capita income by improving employment conditions and by reducing remittances received and national expenditure. Policies on saving should not allow earning interest. Furthermore, in order to increase investment, efforts should be made to lower the interest rate and inflation, and to enhance remittances received and trade. These policies will increase saving and investment in Islamic countries, ultimately resulting in improved economic growth.

Keywords: Interest rate, Economic performance, Islamic countries, Riba, Saving, Investment

JEL classification: E21, E22, E43, O11, Z12, Z13 


\section{Background}

The interest rate is considered an important factor affecting saving and investment. It is generally accepted that the interest rate has a major impact on a country's saving and investment. The interest rate is defined as the cost of borrowing or gain on lending. Typically, a rise in the interest rate encourages people to save more as the former leads to increased income. However, an increase in the interest rate also raises the cost of capital, resulting in a reduction in investment within the economy.

According to Islamic teachings, riba is prohibited. Riba is a practice through which one earns excess returns, where no equivalent counter-value or reward is justified. Riba is an Arabic word, meaning increase or growth; the interest on saving would result in an increase in the final amount payable over and above the original value.

The Qur'an, the Holy Book of the Muslims, notes that, "Whereas Allah permitted trading and forbideth usury," and as Allah has ordered that these practices be shunned, "O ye who believe! Observe your duty to Allah, and give up what remaineth (due to you) from usury, if you are (in truth) believers." Hence, in Islam, while earning interest on saving is disapproved of by Allah, the practice of saving is not prohibited. Moreover, Muslims should "...not spend everything so that you became blameworthy and destitute" (Al-Qur'an 17:29).

Many empirical studies report that people seek monetary rewards regardless of the type of bank they patronize (Islamic or otherwise) for example study of Metwally (1997) conclude that similar returns were offered to the depositors by Islamic and conventional banks; however, this statement is not always true. Consider the example of the Kuwait Finance House, the first bank to operate in accordance with the Islamic Shariah (Islamic Law) established in 1977. According to Haron and Noraffifiah (2000) the bank has not provided depositors interest on their saving in 1984. However, it has enjoyed widespread patronage, and there have been no reports of mass deposit withdrawals. In another example, the Islamic banks of Sudan have never paid their current account holders any kind of income, but a large proportion of their funding is derived from such accounts.

According to the principles of Shariah, wealth should be accumulated by one's own, not others', efforts. The Prophet (PBUH) advised Muslims to work hard to earn their keep and discouraged income generated without any effort, such as through earning interest or riba.

As people in Islamic countries dislike riba or income from saving because of the religious teachings of Islam, it is a general perception that savings in Islamic countries are not affected by changes in the interest rate. Despite this, some banks of Islamic countries implement the practice of the interest rate; in other words, the policy makers of these countries ignore Muslims' shunning of riba, and they continue to imitate the practices of developed non-Muslim countries by implementing economic policies that use the interest rate as a determinant of saving. As many Muslim countries are currently facing a financial crisis, the country's economic policies should be devised in accordance to its population's characteristics to mitigate the impact of such events.

Thus, the aim of this study is to highlight the differences between the effects of the interest rate on saving and investment in Islamic and non-Islamic economies. Because riba or earning income from interest is forbidden according to Islamic teachings, we expect that the interest rate will have different impacts on Islamic and non-Islamic 
countries. If our expectation is found to be true, we propose that the policymakers of Islamic countries use different criteria while making saving-related policies.

This study is conducted using country-level panel data after categorizing the countries as Islamic or non-Islamic. Although many previous studies have covered different aspects of the interest rate with regard to saving and investment, to the best of our knowledge, this is the first study to determine not only the effects of Muslim religious teachings on saving and investment in Muslim countries but also to conduct a comparison between Muslim and non-Muslim countries in this respect. We use the real interest rate to assess its impact on saving and investment in Islamic and non-Islamic countries.

The remainder of this paper is organized as follows. The next section provides a review of the literature. Then, we present the methods and its results. The last section concludes.

\section{Literature review}

\section{Theories related to saving}

According to classical economists, saving is a function of the interest rate. When the latter is high, people tend decrease their present consumption and save more.

However, if we focus on utility maximization, current consumption can change owing to the substitution effect and income effect. In the event of a higher interest rate, the former would lead to a decrease in current consumption, while the latter would have the opposite effect.

High interest rates translate into high borrowing cost for lenders; thus, people try to save more to fulfill their future needs, and theoretically, the interest rate is expected to have a positive relationship with saving.

Classical economists were the first who determine the importance of saving. Smith (1776) states that, "capital is increased by parsimony and diminished by prodigality and misconduct." Keynes (1936) describes saving as the "remaining part of income after all consumption expenses." Thus,

$$
\mathrm{S}=\mathrm{I}-\mathrm{C}
$$

where I, S, and C denote income, saving, and consumption, respectively.

Anyanwu and Oaikhenn (1995) categorize the determinants of saving into two factors.

a) Quantitative factors: They include income level, interest rate, inflation rate, inflation rate expectations, and ease of saving available to a person.

b) Non-quantitative factors: These are psychological factors that affect saving. They include people's need to feel secure against future contingencies or unforeseen events, desire for trust, habitual factors, and social factors.

We can include religious factors, such as Muslims' dislike of riba, under this category.

Theories related to religious, ethical, and social values with regard to saving

Jalaluddin (1992) describes saving in a manner contradictory to Keynes' absolute income hypothesis. According to Jalaluddin, saving is not just the part of income that 
remains after consumption; certain ethical and social responsibilities are linked with saving. A Muslim saves to fulfill his duties toward himself, his family, society, and Almighty Allah. To fulfill these duties, he requires money.

Keynes (1936) notes that in the long run, changes in the interest rate can modify social habits, including the propensity to save.

\section{Theories related to investment}

Economists (e.g., Muhammad et al. 2013) consider investment to be a function of the interest rate and income. Their relationship is defined as under.

$$
\text { Investment }=f(- \text { Interestrate }+\beta 2 \text { Income })
$$

The interest rate increases the cost of borrowing money, and hence, it reduces investments. However, an increase in income raises investment.

Although various studies have discussed the impacts of the interest rate on saving and investment in non-Islamic countries, only a handful refer to Islamic countries. Even so, these studies focus on a single country, or compare Islamic and conventional banks in terms of profitability and saving using country-level panel data. To the best of our knowledge, no study analyzes the bigger picture, namely, the impact of the interest rate on saving and investment by comparing the beliefs of Islamic and non-Islamic countries; specifically, none of the researchers has considered the impact of a population's religious beliefs on the interest rate-saving relationship. We aim to bridge this gap.

According to Khamlichi and Laaradh (2012), Islamic banks, Islamic funds, and indices have not been studied as rigorously owing to their relatively short history of existence. Accordingly, we attempt to compare our results with the available theoretical and empirical literature in this area of research.

There is no consensus regarding the impact of the interest rate on bank deposits and saving in Islamic countries. Kasri and Kassim (2009) conclude that Mudarabah ${ }^{1}$ deposits, a proxy of the saving or investment level in Islamic banks, are positively correlated with the real rate of return on Islamic deposits and negatively correlated with the real interest rate on conventional deposits. According to Kassim et al. (2009), the main reason for Islamic banks being more stable than conventional banks is that the former are not affected by changes in interest rates, and thus, the demand for money stabilizes within the economy. This stability translates into saving, which in turn has a positive impact on monetary policy and the overall financial stability of the economy.

Gerrard and Cunningham (1997) note that Muslims residing in non-Muslim countries like Singapore continue to practice their Islamic beliefs. Thus, they hold their money in Islamic banks, which do not pay interest on saving or investment. However, Metawa and Almossawi (1998) conclude differently from Gerrard and Cunningham (1997). They study the case of Bahrain, where most people practice Islam, and find that while depositors select banks mainly on religious grounds, they also refer to the rate of return. Thus, they note that the rate of return is not the only or primary variable influencing deposit volume in Islamic banks. Khan et al. (1992) conclude that a rise in per capita income will maximize saving.

Many empirical studies on investment and interest rate conclude that interest rate has a significant negative impact on investment. Mohsen and Rezazadeh Karsalari 
(2011) observe a negative relationship between private investment and the real interest rate beyond the threshold level of 5 to $6 \%$, but the impact of real rates on private investment turns positive within this threshold level. Geng and N'Diaye (2012) analyze Chinese data to show that a 100 basis point (bps) increase in the real rate lowers corporate investment by $0.5 \%$ of the gross domestic product (GDP). Using macroeconomic data, Tokuoko (2012) shows a negative relationship between the real interest rate and corporate investment. In their study on the impact of the real interest rate on investment and growth, Pattanaik et al. (2013) observe that a lower interest rate can increase economic growth and investment. However, they advise against any policy move that would reduce the interest rate by increasing tolerance against inflation. Christy and Clendinon (1976) note that the saving rate and interest rate are two important determinants of investment. In their study titled "Determinants of private investment in less developed countries," Greene and Villanueva (1990) consider the data of 23 countries from 1975 to 1985 , and conclude that the interest rate has a negative impact on investment. Hyder and Ahmed (2003) study the reasons for the collapse of private investment in Pakistan and suggest ways to restore the same. They conclude that an increase in the interest rate will lead to a decline in investment.

Larsen (2004), Aysan et al. (2005), Wang and Yu (2007), and Bader and Malawi (2010) identify a negative relationship between interest rate and investment. Conversely, Salahuddin et al. (2009) observe that the interest rate is insignificant with regard to determining investment. They investigate the trends in the investments of 21 developing Muslim countries from 1970 to 2002. Using the fixed effect model, they conclude that debt servicing has a negative impact on investment while all other variables, namely, lagged investment, growth rate of real GDP per capita, domestic saving, institutional development, and trade openness, have a positive impact. Although private sector credit and aid from foreign countries show positive significant impacts, the results are not robust. They further conclude that the lending rate, inflation, growth in population, and human capital have no impact on investment in developing Muslim countries.

Muhammad et al. (2013) study the effect of the interest rate on investment in Pakistan. Using data from 1964 to 2012, they conclude that the interest rate has a negative relationship with investment while income has a positive impact on it.

Nasir and Khalid (2004) study saving and investment trends for Pakistan using time series data for 1971 to 2003. They conclude that budget deficit, government investment, and interest rate are insignificant determinants of saving. Moreover, return on government investment does not have any impact on saving. However, current government expenditure, high income, growth in GDP, and increase in remittances maximize saving. They further conclude that public loan and foreign saving have positive but insignificant impacts, while domestic saving and interest rate have positive significant impacts on investment.

Athukorala (1998) refer to Indian data and conclude that an increase in the interest rate encourages saving and investment, helping the Indian economy to grow.

Expectations and uncertainties are also considered to be important determinants of investment. For instance, any increase in the prices of material or energy will reduce investment. Onwumere et al. (2012) focus on the case of Nigeria and conclude that before liberalization, the interest rate had a positive but non-significant effect on saving 
and investment. After liberalization, however, the interest rate has had a negative nonsignificant effect on saving, and a negative but significant effect on investment.

\section{Methods}

The basic purpose of this study is to investigate the impact of the interest rate on saving and investment in Islamic countries and to compare these results with the corresponding impacts in non-Islamic countries. The purpose of this exercise is to determine whether people in Islamic countries behave differently toward earning income from interest. We use the random effect method and system generalized method of moments (GMM) model for saving and investment. The following subsections provide a description of the data, model specifications, estimation methodologies, and the results.

\section{Data and variables}

We use panel data of 17 non-Islamic and 17 Islamic countries from 2005 to 2013 (lists of included countries are in Appendix). The data are sourced from the World Bank's World Development Indicators (WDI). However, data unavailability for some countries, variables, and earlier years is a limitation for this study. For example, data were not available for a few countries having a sizable Muslim population, such as Saudi Arabia and the UAE (list of such countries is in Appendix). Hence, we exclude such countries from our study. Furthermore, the data for some variables, especially for Islamic countries, were only available from 2005, and thus, our sample data span the years 2005 to 2013.

Our categorization of a country as Islamic is based on the extent of its Muslim population. As explained previously, Muslims respond differently toward the interest rate. Hence, if the majority of a country's population is Muslim, we predict a major impact on its economy, as Muslims respond differently to interest on income. In this study, we categorize a country having $61 \%$ of its population as Muslim as an Islamic country. However average Muslim population in Islamic countries group that have been used in this study is 80 to $90 \%$. In order to maintain consistency, we use the World Bank's recent classification of countries to specify their respective income levels. We have used countries from all income levels such as high income, upper middle, lower middle and lower income. So it is expected that our study's results will be representative for all Islamic and non-Islamic countries.

Notably, all the Islamic and non-Islamic countries referred to in this study are open economies. The variable trade is used as a proxy of degree of openness. Moreover all Islamic countries allows interest on saving that is why we are able to include data of variable real interest rate in our study. Although Kuwait is not included in our Islamic countries list in this study because of data unavailability but Kuwait also allows interest rate. Kuwait Finance house is an institution just similar to Islamic Banks in other countries and there were an incident in 1984 describe by Haron and Noraffifiah (2000) which we have used as reference in favor of people's religious patronization. 


\section{Descriptive statistics}

Table 1 presents the descriptive statistics of the 17 Islamic and 17 non-Islamic countries referred to in this study.

We note that all the variables are positively skewed for the Islamic countries, while only gross domestic saving (GDS) is negatively skewed for non-Islamic countries. As all the other variables are positively skewed, they are skewed to the right. The values of kurtosis for both Islamic and non-Islamic countries are positive (platykurtic).

The means of the variables show that except for RIR and DCBS, the average values of the Islamic countries exceed those of the non-Islamic countries. Standard deviation is a measure of risk, and the behavior of the variables shows that GDPdef, RIR, DCBS, GNE, and PRR have more variations for non-Islamic countries, while the same is true for GDS, GCF, T, and GPCC for Islamic countries.

\section{Unit root test}

In order to apply the regression method, all variables must be stationary. We use the unit root test to check this requirement. Levin et al. (2002), presented the unit root test for panel data, the null hypothesis being that each time series contains a unit root against the alternative hypothesis that each time series is stationary.

Table 1 Descriptive statistics

\begin{tabular}{|c|c|c|c|c|c|c|c|c|c|}
\hline & GDS & GCF & GDPdef & $\mathrm{RIR}$ & $\mathrm{T}$ & DCBS & GNE & PRR & GPCC \\
\hline \multicolumn{10}{|l|}{ Non-Muslim countries } \\
\hline Mean & 15.376 & 25.449 & 8.827 & 8.232 & 76.199 & 38.560 & $1.21 E+14$ & $2.66 \mathrm{E}+09$ & 228 \\
\hline Median & 18.059 & 24.168 & 6.553 & 6.135 & 68.627 & 28.822 & $3.78 \mathrm{E}+12$ & $9.15 E+08$ & 109 \\
\hline Maximum & 44.719 & 41.412 & 75.438 & 44.635 & 163.336 & 148.340 & $1.36 E+15$ & $2.69 E+10$ & 274 \\
\hline Minimum & -23.999 & 11.186 & -3.005 & -33.651 & 22.105 & 1.201 & $2.41 E+09$ & 11470.900 & 1327 \\
\hline Std. Dev. & 13.588 & 6.720 & 9.775 & 10.717 & 33.664 & 33.194 & $2.98 E+14$ & $5.63 E+09$ & 603 \\
\hline Skewness & -0.646 & 0.370 & 4.102 & 0.329 & 0.469 & 1.573 & 2.824 & 3.311 & 3.165 \\
\hline Kurtosis & 3.404 & 2.619 & 26.155 & 6.402 & 2.194 & 5.089 & 10.121 & 13.066 & 11.957 \\
\hline No. of observations & 153 & 153 & 153 & 153 & 153 & 153 & 153 & 153 & 153 \\
\hline \multicolumn{10}{|l|}{ Muslim countries } \\
\hline Mean & 16.997 & 26.135 & 8.462 & 5.744 & 84.406 & 35.500 & $6.21 E+14$ & $2.78 \mathrm{E}+09$ & 400 \\
\hline Median & 14.263 & 26.144 & 6.764 & 5.747 & 74.744 & 27.687 & $5.68 \mathrm{E}+11$ & $1.21 \mathrm{E}+09$ & 18824.54 \\
\hline Maximum & 61.142 & 46.876 & 34.340 & 48.055 & 203.854 & 119.982 & $9.60 E+15$ & $1.92 E+10$ & 324 \\
\hline Minimum & -34.607 & 9.341 & -25.128 & -19.926 & 34.396 & 1.551 & $4.39 E+09$ & 31000. & 418.7 \\
\hline Std. Dev. & 24.741 & 7.445 & 9.164 & 10.406 & 35.008 & 28.400 & $\begin{array}{l}1.85 E+ \\
15\end{array}$ & $3.71 E+09$ & 876 \\
\hline Skewness & 0.016 & 0.143 & 0.117 & 0.980 & 1.151 & 1.217 & 3.228 & 2.039 & 2.142 \\
\hline Kurtosis & 1.868 & 2.682 & 4.813 & 5.860 & 4.123 & 3.645 & 12.804 & 7.359 & 6.018 \\
\hline No. of observations & 153 & 153 & 153 & 153 & 153 & 153 & 153 & 153 & 153 \\
\hline
\end{tabular}

Note: GDPdef inflation, GDP deflator (annual \%), GDS Gross domestic saving (\% of GDP), GCF Gross capital formation (\% of GDP), RIR real interest rate (\%), $T$ trade (\% of GDP), DCBS domestic credit provided to the private sector by banks (\% of GDP), GNE Gross national expenditure (current LCU), PRR personal remittances received (current US\$), GPCC GDP per capita (constant LCU), LCU local currency unit 
The results of the unit root test appear in Table 2. The majority of the variables are stationary, and thus, we can use the above-mentioned regression because the needed condition has been fulfilled.

\section{Model specification tests}

As we use panel data, we need to select the most appropriate model from among the simple ordinary least squares (OLS), fixed effect, and random effect models. We attempt this with the model specification tests. The results of these tests appear in Table 3, indicating that the random effect model is the most appropriate for our purpose.

\section{Random effect model}

In the random effect model, variations across entities are assumed to be random and uncorrelated with independent variables in the model.

We build separate models for Islamic and non-Islamic countries. The mathematical form of our basic models using the random effect method is specified as under.

$$
\begin{aligned}
& G D S_{i t}=\beta_{1} R I R_{i t}+\beta_{2} G N E_{i t}+\beta_{3} P R R_{i t}+\beta_{4} D C B S_{i t}+\beta_{5} \text { GDPdef }_{i t} \\
& +\beta_{6} G P C C_{i t}+\beta_{7} T_{i t}+\alpha+\mu_{i t}+\varepsilon_{i t} \\
& G C F_{i t}=\beta_{1} R I R_{i t}+\beta_{2} G N E_{i t}+\beta_{3} P R R_{i t}+\beta_{4} D C B S_{i t}+\beta_{5} \text { GDPdef }_{i t} \\
& +\beta_{6} G P C C_{i t}+\beta_{7} T_{i t}+\alpha+\mu_{i t}+\varepsilon_{i t}
\end{aligned}
$$

Table 2 Results of Levin et al.'s (2002) unit root test (common root)

\begin{tabular}{llllllll}
\hline Variable & Islamic countries & & & & Non-Islamic countries & \\
& Individual intercept & $\begin{array}{l}\text { Individual intercept } \\
\text { and trend }\end{array}$ & None & & Individual intercept & $\begin{array}{l}\text { Individual intercept } \\
\text { and trend }\end{array}$ & None \\
\hline GDPdef & -3.249 & -5.294 & -1.331 & -7.379 & -10.935 & -2.801 \\
& $(0.000)$ & $(0.000)$ & $(0.092)$ & $(0.000)$ & $(0.000)$ & $(0.002)$ \\
GDS & -3.535 & -9.072 & -1.900 & -3.067 & -8.423 & -787 \\
& $(0.000)$ & $(0.000)$ & $(0.028)$ & $(0.001)$ & $(0.000)$ & $(0.216)$ \\
GCF & -6.207 & -15.287 & 0.455 & -4.245 & -5.050 & 1.147 \\
& $(0.000)$ & $(0.000)$ & $(0.675)$ & $(0.000)$ & $(0.000)$ & $(0.874)$ \\
RIR & -4.478 & -5.318 & -1.962 & -12.570 & -17.968 & -3.759 \\
& $(0.000)$ & $(0.000)$ & $(0.024)$ & $(0.000)$ & $(0.000)$ & $(0.000)$ \\
T & -4.563 & -7.432 & -0.356 & -5.706 & -48.383 & 1.052 \\
& $(0.000)$ & $(0.000)$ & $(0.361)$ & $(0.000)$ & $(0.000)$ & $(0.853)$ \\
DCBS & -5.905 & -3.792 & 0.631 & -2.456 & -10.384 & 1.765 \\
& $(0.000)$ & $(0.000)$ & $(0.736)$ & $(0.007)$ & $(0.000)$ & $(0.961)$ \\
GNE & 0.327 & -2.224 & -1.732 & -4.529 & -4.487 & 4.509 \\
& $(0.628)$ & $(0.013)$ & $(0.010)$ & $(0.000)$ & $(0.000)$ & $(0.800)$ \\
PRR & -4.325 & -29.221 & 2.510 & -3.023 & -10.182 & -0.359 \\
& $(0.000)$ & $(0.000)$ & $(0.994)$ & $(0.001)$ & $(0.000)$ & $(0.359)$ \\
GPCC & -3.590 & -5.286 & 3.450 & -1.904 & -4.779 & 3.791 \\
& $(0.000)$ & $(0.000)$ & $(0.999)$ & $(0.028)$ & $(0.000)$ & $(0.999)$ \\
\hline
\end{tabular}


Table 3 Results of the model specification test for panel data

\begin{tabular}{|c|c|c|c|c|c|c|}
\hline \multirow{2}{*}{$\begin{array}{l}\text { Specification } \\
\text { test }\end{array}$} & \multirow[t]{2}{*}{ Tested } & \multicolumn{2}{|c|}{ Islamic countries } & \multicolumn{2}{|c|}{ Non-Islamic countries } & \multirow[t]{2}{*}{ Selection } \\
\hline & & Saving & Investment & Saving & Investment & \\
\hline \multirow[t]{2}{*}{ F-test } & OLS/ & 242.06 & 22.09 & 73.90 & 19.30 & \multirow[t]{2}{*}{ Fixed } \\
\hline & fixed & $(0.000)$ & $(0.000)$ & $(0.000)$ & $(0.000)$ & \\
\hline Breusch- & OLS/ & 528.29 & 247.34 & 414.98 & 239.75 & \multirow[t]{3}{*}{ Random } \\
\hline Pagan & random & $(0.000)$ & $(0.000)$ & $(0.000)$ & $(0.000)$ & \\
\hline \multicolumn{6}{|l|}{ (LM) } & \\
\hline \multirow[t]{2}{*}{ Hausman } & Fixed/ & 4.863 & 9.248 & 6.885 & 9.949 & \multirow[t]{2}{*}{ Random } \\
\hline & random & $(0.676)$ & $(0.235)$ & $(0.441)$ & $(0.191)$ & \\
\hline
\end{tabular}

Note: The definitions of the variables appear in the note under Table 1. The figures in parentheses are the $p$-values of the $t$-statistics. "LM" stands for Lagrange multiplier

where $\alpha$ is the intercept term, $\beta$ refers to the coefficients of the independent variable$\mathrm{s}^{\prime} \mu i t$ is the between entity error, and ${ }^{\varepsilon} i t$ is the within entity error. (The definitions of the variables appear in the note under Table 1).

In this study, gross domestic saving (\% of GDP) and gross capital formation (\% of GDP) are used as the proxy of saving and the proxy of investment, respectively.

In line with the theories and the findings of previous studies, we expect that the interest rate will have a positive impact on saving and a negative impact on investment in non-Islamic countries. However, given the religious factor of dislike toward income from interest, we expect that the interest rate will have an insignificant effect on saving in Islamic countries.

\section{Endogeneity and GMM}

There is a possibility of endogeneity in regression models. Endogeneity can arise because of i) a bidirectional relationship between the dependent and independent variables (also called reverse causality), ii) measurement error, iii) omitted variables, or iv) the existence of a correlation between a variable of the model and the error term.

Growth models have variables that can determine endogeneity. As the GMM model can control endogeneity in the data, we use the Arellano-Bover linear dynamic panel estimation for system GMM (Arellano and Bover 1995).

\section{Arellano-Bover estimation for system GMM (orthogonality condition)}

The basic equation of the Arellano-Bover estimation for system GMM is as under. We use this equation to model saving and investment in Islamic and non-Islamic countries.

$$
\begin{aligned}
\Delta y_{i t}= & \gamma_{t}+(\alpha-1) y_{i, t-1}+x^{\prime} \beta_{i t}+x^{\prime}{ }_{i t} \beta_{2}+x^{\prime}{ }_{i t} \beta_{3}+x^{\prime} \beta_{i t} \beta_{4}+x^{\prime} \beta_{i t}+x_{5}^{\prime}{ }_{i t} \beta_{6} \\
& +x^{\prime}{ }_{i t} \beta_{7}+\eta_{i}+v_{i t}
\end{aligned}
$$

where $\Delta y_{i t}$ is the log difference of the dependent variable, $y_{i t}$ is the logarithm of the dependent variable at the start of period $t$, and $x_{i t}$ is the vector of characteristics measured during or at the start of period $t$. Among other things, $\eta_{i}$ refers to unobserved country-specific effects, while $\gamma_{t}$ refers to period-specific intercepts. Country effects and time effects may also reflect country-specific and period-specific components, respectively, of the measurement error $v_{i t}$. 


\section{Results}

The correlation matrices showing the correlations among the independent variables of the Islamic and non-Islamic countries appear in Table 4.

The regression results of the random effect and system GMM models are shown in Table 5.

Table 6 summarizes the results of all the models.

Table 4 Correlation matrices

\begin{tabular}{|c|c|c|c|c|c|c|c|}
\hline \multicolumn{8}{|c|}{ Muslim countries: Model 3 for saving } \\
\hline & RIR & GNE & PRR & DCBS $(-1)$ & GDPDEF & LOG (GPCC) & $\mathrm{T}$ \\
\hline $\mathrm{RIR}$ & 1.000 & -0.232 & -0.144 & -0.271 & -0.606 & -0.187 & -0.046 \\
\hline GNE & -0.232 & 1.000 & 0.133 & 0.023 & 0.231 & 0.623 & -0.348 \\
\hline PRR & -0.144 & 0.133 & 1.000 & 0.207 & 0.055 & 0.159 & -0.284 \\
\hline DCBS $(-1)$ & -0.271 & 0.023 & 0.207 & 1.000 & -0.110 & 0.112 & 0.549 \\
\hline GDPdef & -0.606 & 0.231 & 0.055 & -0.110 & 1.000 & 0.051 & -0.076 \\
\hline LOG (GPCC) & -0.187 & 0.623 & 0.159 & 0.112 & 0.051 & 1.000 & -0.294 \\
\hline T & -0.046 & -0.348 & -0.284 & 0.549 & -0.076 & -0.294 & 1.000 \\
\hline \multicolumn{8}{|c|}{ Non-Muslim countries: Model 1 for saving } \\
\hline & RIR & GNE & PRR & DCBS $(-1)$ & GDPDEF & LOG (GPCC) & $\mathrm{T}$ \\
\hline RIR & 1.000 & -0.198 & -0.122 & -0.106 & -0.461 & -0.244 & -0.373 \\
\hline GNE & -0.198 & 1.000 & 0.150 & 0.622 & -0.041 & 0.680 & 0.079 \\
\hline PRR & -0.122 & 0.150 & 1.000 & 0.007 & -0.159 & 0.115 & -0.172 \\
\hline DCBS $(-1)$ & -0.106 & 0.622 & 0.007 & 1.000 & -0.231 & 0.253 & 0.321 \\
\hline GDPdef & -0.461 & -0.041 & -0.159 & -0.231 & 1.000 & 0.072 & 0.198 \\
\hline LOG (GPCC) & -0.244 & 0.680 & 0.115 & 0.253 & 0.072 & 1.000 & -0.110 \\
\hline $\mathrm{T}$ & -0.373 & 0.079 & -0.172 & 0.321 & 0.198 & -0.110 & 1.000 \\
\hline \multicolumn{8}{|c|}{ Muslim countries: Model 4 for investment } \\
\hline & RIR & GNE & PRR & DCBS & GDPDEF & LOG (GPCC) & $\mathrm{T}$ \\
\hline $\mathrm{RIR}$ & 1.000 & -0.225 & -0.130 & -0.218 & -0.604 & -0.199 & -0.080 \\
\hline GNE & -0.225 & 1.000 & 0.144 & 0.023 & 0.225 & 0.611 & -0.332 \\
\hline PRR & -0.130 & 0.144 & 1.000 & 0.203 & 0.033 & 0.172 & -0.271 \\
\hline DCBS & -0.218 & 0.023 & 0.203 & 1.000 & -0.170 & 0.119 & 0.557 \\
\hline GDPdef & -0.604 & 0.225 & 0.033 & -0.170 & 1.000 & 0.074 & -0.046 \\
\hline LOG (GPCC) & -0.199 & 0.611 & 0.172 & 0.119 & 0.074 & 1.000 & -0.280 \\
\hline T & -0.080 & -0.332 & -0.271 & 0.557 & -0.046 & -0.280 & 1.000 \\
\hline \multicolumn{8}{|c|}{ Non-Muslim countries: Model 2 for investment } \\
\hline & RIR & GNE & PRR & DCBS & GDPDEF & LOG (GPCC) & $\mathrm{T}$ \\
\hline RIR & 1.000 & -0.191 & -0.116 & -0.070 & -0.426 & -0.241 & -0.357 \\
\hline GNE & -0.191 & 1.000 & 0.150 & 0.614 & -0.061 & 0.674 & 0.068 \\
\hline PRR & -0.116 & 0.150 & 1.000 & 0.009 & -0.167 & 0.115 & -0.170 \\
\hline DCBS & -0.070 & 0.614 & 0.009 & 1.000 & -0.298 & 0.251 & 0.310 \\
\hline GDPdef & -0.426 & -0.061 & -0.167 & -0.298 & 1.000 & 0.053 & 0.157 \\
\hline LOG (GPCC) & -0.241 & 0.674 & 0.115 & 0.251 & 0.053 & 1.000 & -0.120 \\
\hline T & -0.357 & 0.068 & -0.170 & 0.310 & 0.157 & -0.120 & 1.000 \\
\hline
\end{tabular}

Note: The definitions of the variables appear in the note under Table 1 
Table 5 Empirical results

\begin{tabular}{|c|c|c|c|c|c|c|c|c|}
\hline \multirow[t]{3}{*}{ Variable } & \multicolumn{4}{|c|}{ Non-Islamic countries } & \multicolumn{4}{|l|}{ Islamic countries } \\
\hline & \multicolumn{2}{|l|}{$\begin{array}{l}\text { Model } 1 \\
\text { Saving }\end{array}$} & \multicolumn{2}{|l|}{$\begin{array}{l}\text { Model } 2 \\
\text { Investment }\end{array}$} & \multicolumn{2}{|l|}{$\begin{array}{l}\text { Model } 3 \\
\text { Saving }\end{array}$} & \multicolumn{2}{|l|}{$\begin{array}{l}\text { Model } 4 \\
\text { Investment }\end{array}$} \\
\hline & Random effect & GMM & Random effect & GMM & Random effect & GMM & Random effect & GMM \\
\hline Constant & $9.153(0.605)$ & -————- & $16.875(0.045)$ & -—————- & $-159.500(0.139)$ & -—-———- & $20.272(0.0071)$ & -二-———— \\
\hline Real interest rate & $0.178(0.106)$ & $0.106(0.037)$ & $-0.147(0.042)$ & $-0.188(0.041)$ & $0.153(0.489)$ & $0.036(0.845)$ & $-0.192(0.204)$ & $-0.282(0.032)$ \\
\hline National expenditure & $1.48 \mathrm{E}-14(0.021)$ & $-9.37 \mathrm{E}-15(0.000)$ & $3.86 \mathrm{E}-15(0.339)$ & $-7.96 \mathrm{E}-16(0.813)$ & $7.24 \mathrm{E}-16(0.255)$ & $-1.16 \mathrm{E}-15(0.011)$ & $9.28 \mathrm{E} 16(0.021)$ & $8.01 \mathrm{E}-17(0.805)$ \\
\hline Remittances received & $-1.36 \mathrm{E}-10(0.788)$ & 4.23E-10 (0.361) & $-9.23 \mathrm{E}-11(0.707)$ & $6.48 \mathrm{E}-11(0.932)$ & $-5.52 \mathrm{E}-10(0.1319)$ & $-3.15 E-10(0.024)$ & $4.98 \mathrm{E}-11(0.796)$ & $3.14 \mathrm{E}-10(0.001)$ \\
\hline $\begin{array}{l}\text { Domestic credit provided } \\
\text { by banks }\end{array}$ & $-0.087(0.191)$ & $-0.047(0.313)$ & $-0.035(0.335)$ & $-0.178(0.045)$ & $-0.284(0.017)$ & $-0.090(0.265)$ & $-0.009(0.857)$ & $-0.019(0.762)$ \\
\hline Inflation & $0.034(0.650)$ & $0.103(0.011)$ & $-0.091(0.089)$ & $-0.161(0.099)$ & $0.138(0.55)$ & $0.247(0.289)$ & $-0.219(0.175)$ & $-0.252(0.059)$ \\
\hline Per capita income & $1.195(0.406)$ & $1.98 \mathrm{E}-06(0.018)$ & $0.721(0.261)$ & 3.80E-07 (0.379) & $16.201(0.098)$ & $1.43 \mathrm{E}-06(0.000)$ & $0.067(0.902)$ & $-5.51 \mathrm{E}-08(0.555)$ \\
\hline Trade & $-0.098(0.052)$ & $0.041(0.134)$ & $0.043(0.128)$ & $0.076(0.048)$ & $0.107(0.07)$ & $-0.055(0.277)$ & $0.091(0.002)$ & $0.107(0.000)$ \\
\hline$R^{2}$ & 0.92 & -二-二-二 & 0.77 & -——-—— & 0.974 & -二-二-二 & 0.77 & -二-二-二- \\
\hline F-statistic & $3.038(0.005)$ & -二-二-二 & $2.756(0.024)$ & -二-二—— & $158.437(0.000)$ & 一二-二-二 & $2.653(0.013)$ & -二-二- \\
\hline $\begin{array}{l}\text { No. of } \\
\text { Instruments }\end{array}$ & -———- & 20 & -二-—— & 22 & & 20 & & 22 \\
\hline Sargan test & -二-二-— & $11.053(0.438)$ & -ー-ー-—- & $10.629(0.642)$ & --—-ー- & $7.272(0.776)$ & & $4.918(0.977)$ \\
\hline Arellano-Bond test, AR (1) & -二-二-— & $-1.524(0.127)$ & -二-二-— & $-2.789(0.005)$ & -二-二-— & $-2.173(0.029)$ & -二-二-二 & $-2.520(0.011)$ \\
\hline Arellano-Bond test, AR (2) & -二————- & $-0.967(0.333)$ & -——-——- & $-0.859(0.390)$ & -—————— & $-1.304(0.192)$ & -二-二-二 & $-1.683(0.159)$ \\
\hline
\end{tabular}


Table 6 Summary of results

\begin{tabular}{|c|c|c|c|c|}
\hline \multirow[t]{3}{*}{ Variable } & \multicolumn{2}{|c|}{ Non-Islamic countries } & \multicolumn{2}{|c|}{ Islamic countries } \\
\hline & Model 1 & Model 2 & Model 3 & Model 4 \\
\hline & Saving & Investment & Saving & Investment \\
\hline Real interest rate & $\begin{array}{l}\text { Positive and } \\
\text { significant }\end{array}$ & $\begin{array}{l}\text { Negative and } \\
\text { significant }\end{array}$ & $\begin{array}{l}\text { Positive and } \\
\text { insignificant }\end{array}$ & $\begin{array}{l}\text { Negative and } \\
\text { significant }\end{array}$ \\
\hline National expenditure & $\begin{array}{l}\text { Negative and } \\
\text { significant }\end{array}$ & $\begin{array}{l}\text { Negative and } \\
\text { insignificant }\end{array}$ & $\begin{array}{l}\text { Negative and } \\
\text { significant }\end{array}$ & $\begin{array}{l}\text { Positive and } \\
\text { insignificant }\end{array}$ \\
\hline Remittances received & $\begin{array}{l}\text { Positive and } \\
\text { insignificant }\end{array}$ & $\begin{array}{l}\text { Positive and } \\
\text { insignificant }\end{array}$ & $\begin{array}{l}\text { Negative and } \\
\text { significant }\end{array}$ & $\begin{array}{l}\text { Positive and } \\
\text { significant }\end{array}$ \\
\hline $\begin{array}{l}\text { Domestic credit provided } \\
\text { by banks }\end{array}$ & $\begin{array}{l}\text { Negative and } \\
\text { insignificant }\end{array}$ & $\begin{array}{l}\text { Negative and } \\
\text { significant }\end{array}$ & $\begin{array}{l}\text { Negative and } \\
\text { insignificant }\end{array}$ & $\begin{array}{l}\text { Negative and } \\
\text { insignificant }\end{array}$ \\
\hline Inflation & $\begin{array}{l}\text { Positive and } \\
\text { significant }\end{array}$ & $\begin{array}{l}\text { Negative and } \\
\text { significant }\end{array}$ & $\begin{array}{l}\text { Positive and } \\
\text { insignificant }\end{array}$ & $\begin{array}{l}\text { Negative and } \\
\text { significant }\end{array}$ \\
\hline Per capita income & $\begin{array}{l}\text { Positive and } \\
\text { significant }\end{array}$ & $\begin{array}{l}\text { Positive and } \\
\text { insignificant }\end{array}$ & $\begin{array}{l}\text { Positive and } \\
\text { significant }\end{array}$ & $\begin{array}{l}\text { Negative and } \\
\text { insignificant }\end{array}$ \\
\hline Trade & $\begin{array}{l}\text { Positive and } \\
\text { insignificant }\end{array}$ & $\begin{array}{l}\text { Positive and } \\
\text { significant }\end{array}$ & $\begin{array}{l}\text { Negative and } \\
\text { insignificant }\end{array}$ & $\begin{array}{l}\text { Positive and } \\
\text { significant }\end{array}$ \\
\hline
\end{tabular}

\section{Conclusions and recommendations}

This study confirms that although the interest rate is an important determinant factor of saving and investment, as believed by many researchers, religious factors also play a vital role. The latter can affect the behavior of an investor regarding his decision to save and his response toward incentives being offered (i.e., interest income) for saving. Thus, the governments/policy makers of Islamic countries should not imitate the economic policies of other non-Islamic countries by giving undue importance to the interest rate. This can be one of the reasons for the failure of economic policy, leading to financial crises, in most Muslim countries. Our results for relationship between interest rate and saving are similar to those of Nasir and Khalid (2004) in the case of Islamic countries and Athukorala (1998) in the case of non-Islamic countries.

Instead of giving importance to the interest rate in their economic policies, Muslim countries should try to increase per capita income, reduce remittances received and national expenditure, and improve employment conditions in their countries to increase saving. They should also attempt to lower the lending interest rate and inflation, and increase trade and remittances received to increase investment. Thus, Muslim countries can increase investment and saving, and achieve positive economic growth.

On the other hand, the governments of non-Muslim countries should continue to pay heed to the interest rate while devising their economic policies. They should attempt increasing per capita income, inflation (but keep in check to maintain a healthy level of inflation), and the interest rate but lower national expenditure in order to increase saving.

With regard to improving investment, the governments of non-Muslim countries should try to decrease inflation, domestic credit offered by banks, and the interest rate, while attempting to increase trade in order to increase investment.

Nasir and Khalid (2004) point out that saving and investment are the tools for economic growth. Thus, economic policies that are out of step with a population's religious beliefs (as seen in Islamic countries) are unlikely to promote economic growth. Thus, our results suggest the need for harmonizing economic policies accordingly. Doing so 
would increase savings in Islamic countries. Muslim countries should therefore shun interest on saving because of their populations' negative response toward the interest rate in the saving model.

\section{Limitations and scope for future research}

This study presents a new concept in economic study, namely, the impact of religious beliefs on country-level economic variables. This concept can be expanded to include countries, new variables and timeframes, and novel statistical techniques (e.g., using time series or cross sectional data). However, the unavailability of data, especially for certain Muslim countries, can pose a significant limitation.

\section{Endnotes}

1"Mudarabah" is a special kind of partnership where one partner gives money to another for investing it in a commercial enterprise. The investment comes from the first partner who is called "rabb-ul-mal", while the management and work is an exclusive responsibility of the other, who is called "mudarib”. (Uusmani and Taqī ‘Uśnānī 2002).

\section{Appendix}

\section{List of $\mathbf{1 7}$ non -Muslim countries used in this study}

Armenia, Belarus, Belize, Bolivia, Colombia, Korea. Rep, Mauritius, Mexico, Moldova, South Africa, Tanzania, Uganda, Botswana, Brazil, Burundi, Congo, Haiti.

List of 17 Muslim countries used in this study: (Muslim population is more than $61 \%$ of total population)

Albania, Algeria, Azerbaijan, Bangladesh, Comoros, Egypt, Indonesia, Iran, Iraq, Jordan, Kosovo, Kyrgyz Republic, Lebanon, Malaysia, Oman, Tajikistan, The Gambia.

List of Muslim countries not included in this study because of data unavailability for required variables: (Muslim population is more than $61 \%$ of total population) Afghanistan, Bahrain, Brunei Darussalam, Burkina Faso, Cyprus, Djibouti, Guinea, Kazakhstan, Kuwait, Libya, Maldives, Mali, Mauritania, Morocco, Niger, Pakistan, Qatar, Saudi Arabia, Senegal, Somalia, Sudan, Syrian Arab Republic, Tunisia, Turkey, Turkmenistan, United Arab Emirates, Uzbekistan, Yemen, Rep.

Acknowledgements

The authors are grateful to their families and colleagues for their cooperation.

Author's contributions

First Author Contribution: First Author (SM) has collected and analyzed the data and prepared the first draft of the article. Second Author Contribution: Second Author (DAS) has revised the first draft and made necessary changes. Both authors read and approved the final manuscript.

Authors' information

Saba Mushtaq is PhD scholar at Department of Business Administration (Karachi University Business School), University of Karachi, Karachi, Pakistan.

Dr. Danish Ahmed Siddiqui is Associate Professor at Department of Business Administration (Karachi University

Business School), University of Karachi, Karachi, Pakistan. 
Received: 15 December 2015 Accepted: 21 July 2016

Published online: 29 July 2016

\section{References}

Anyanwu JC, Oaikhenan HE (1995) Modern macroeconomics : theory and applications in Nigeria"

Arellano M, Bover O (1995) Another look at the instrumental variable estimation of error-components models. J Econ 68(1):29-51

Athukorala PC (1998) Interest rates, saving and investment: evidence from India. J Oxford Development Studies 26:2

Aysan, A., Gaobo, P. and Marie-Ange Veganzones-Varoudakis. (2005). How to Boost Private Investment in the MENA Countries: The Role of Economic Reforms. Topics in Middle Eastern and North African Economics, MEEA, Online Journal, (VII): 1-15. [Online] Available: http://www.luc.edu/orgs/meea/volume7/Aysan.pdf

Bader M, Malawi Al (2010) The impact of interest rate on investment in Jordan: a cointegration analysis. Journal of King Abdul Aziz University: Economics and Administration 24(1):199-209

Christy and Clendenin (1976) Introduction to Investment. Bellwood Publishers, pp.24-53

El Khamlichi A, K. Laaradh (2012) Performance persistence of Islamic Equity Mutual Funds, International Islamic Capital Market Conference, pp. 19-20

Geng, Nan and N'Diaye Papa (2012) Determinants of corporate investment in China: Evidence from cross-country firm level data. IMF Working Paper No. WP/ 12/80, International Monetary Fund

Gerrard P, Barton Cunningham J (1997) Islamic banking: a study in Singapore". Int J Bank Mark 15(6):204

Greene J, Villanueva D (1990) Determinants of private investment in LDCs. Finance and Development 27(4):40

Haron, Noraffifah A (2000) The effect of conventional interest rates and rate of profit on funds deposited with Islamic Banking System in Malaysia. International Journal of Islamic Financial Services 1:3

Hyder K, Ahmed QM (2003) Why private investment in Pakistan has collapsed and how it can be restored. Lahore J Econ 9.1:108

Jalaluddin AKM (1992) Savings behaviour in Islamic framework. Econ Bull (Persatuan Ekonomi, Kajian Perniagaan dan Pengurusan, Shah Alam) 2(3):71-85

Onwumere JUJ, Okore OA, Ibe IG (2012) The impact of interest rate liberalization on savings and investment: Evidence from Nigeria". RJFA 3:10

Kasri RA, Kassim SH (2009) Empirical determinants of saving in the Islamic banks: evidence from Indonesia". J King Abdulaziz University: Islamic Economics 22:181-201

Kassim S, Majid MA, Yusof RM (2009) Impact of monetary policy shocks on conventional and Islamic banks in a dual banking system: evidence from Malaysia. J Econ Coop Dev 30:41-58

Keynes JM (1936) The General Theory of Employment, Interest and Money". Macmillan, London

Khan AH, Hasan L, Malik A, Knerr B (1992) dependency ratio, foreign capital inflows and the rate of savings in Pakistan [with comments]. The Pakistan Dev Rev 31(4):843-856

Larsen EJ (2004) The impact of loan rates on direct real estate investment holding period return. Financial Services Review 13:111-121

Levin A, Lin CF, Chu CSJ (2002) Unit root tests in panel data: asymptotic and finite-sample properties. J Econ 108(1):1-24

Mohsen M, Rezazadeh Karsalari A (2011) The non-linear relationship between private investment and real interest rates based on dynamic threshold panel: the case of developing countries. JMIB 21:32-42

Metawa SA, Almossawi M (1998) Banking behavior of Islamic bank customers: perspectives and implications. IJBM 16:299-313

Metwally MM (1997) Differences between the financial characteristics of interest-free banks and conventional banks. Eur Bus Rev 97(2):92-98

Muhammad DS, Lakhan R, Ghulam M, Numan (2013) Rate of interest and its impact on investment to the extent of Pakistan. Pakistan Journal of Commerce and Social Sciences 7(1):91-99

Nasir S, Khalid M (2004) Saving-investment behaviour in Pakistan: an empirical investigation. The Pakistan Dev Rev 43(4):665-682

Pattanaik, Behera, Rajesh (2013) Real interest rate impact on investment and growth-What the empirical evidence for India suggests. Reserve Bank of India. Available at https://www.rbi.org.in/Scripts/PublicationsView.aspx?id=15113

Salahuddin M, Islam MR, Salim SA (2009) Determinants of investment in muslim Developing countries:An empirical investigation". Int J Econ Manag 3(1):100-129

Smith A (1776) An inquiry into the nature and causes of the wealth of nations: Volume One

The Qur'an, the Holy Book of the Muslims

Tokuoka, Kiichi (2012) Does the Business Environment Affect Corporate Investment in India? IMF Working Paper, WP/12/70. Uusmani MT, Taqii 'Usmānī M (2002) An introduction to Islamic finance (Vol. 20). Brill.

Wang DH, Yu TH (2007) The role of interest rate in investment decisions: a fuzzy logic framework. Global Business and Economic Review 9(4):448-457

World Bank development indicators (WDI) (various issues) 